\title{
Lulo cell line derived from Lutzomyia longipalpis (Diptera: Psychodidae): a novel model to assay Leishmania spp. and vector interaction
}

\author{
Luzia MC Côrtes ${ }^{1}$, Roger MM Silva², Bernardo AS Pereira ${ }^{1}$, Camila Guerra², Angela C Zapata ${ }^{3}$, Felio J Bello ${ }^{4}$, \\ Léa C Finkelstein ${ }^{5}$, Maria F Madeira ${ }^{6}$, Reginaldo P Brazil', Suzana Côrte-Real ${ }^{2}$ and Carlos R Alves ${ }^{1 *}$
}

\begin{abstract}
Background: Leishmania (Vianna) braziliensis, Leishmania (Leishmania) amazonensis and Leishmania (Leishmania) chagasi are important parasites in the scenario of leishmaniasis in Brazil. During the life cycle of these parasites, the promastigote forms adhere to the midgut epithelial microvillii of phlebotomine insects to avoid being secreted along with digestive products. Lulo cells are a potential model that will help to understand the features of this adhesion phenomenon. Here, we analyze the interaction between Leishmania spp. promastigotes and Lulo cells in vitro, specifically focusing on adhesion events occurring between three Leishmania species and this cell line.
\end{abstract}

Methods: Confluent monolayers of Lulo cells were incubated with promastigotes and adhesion was assessed using both light microscopy and scanning electron microscopy.

Findings: The results indicate that species from the subgenera Leishmania and Viannia have great potential to adhere to Lulo cells. The highest adherence rate was observed for $L$. (L.) chagasi after $24 \mathrm{~h}$ of incubation with Lulo cells $(27.3 \pm 1.8 \%$ of cells with adhered promastigotes), followed by $L$. (L.) amazonensis $(16.0 \pm 0.7 \%)$ and $L$. (V.) braziliensis $(3.0 \pm 0.7 \%)$, both after $48 \mathrm{~h}$. In the ultrastructural analysis, promastigote adherence was also assessed by scanning electron microscopy, showing that, for parasites from both subgenera, adhesion occurs by both the body and the flagellum. The interaction of Lulo cells with Leishmania (L.) chagasi showed the participation of cytoplasmic projections from the former closely associating the parasites with the cells.

Conclusions: We present evidence that Lulo cells can be useful in studies of insect-parasite interactions for Leishmania species.

Keywords: Leishmania spp, Lulo cell, Phlebotominae, promastigotes

\section{Findings}

Leishmaniases are infections that affect humans, wildlife and domestic animals, and present an array of clinical manifestations, varying from tegumentary (mucocutaneous, cutaneous and diffuse) to visceral. Species of the genus Leishmania are present in all continents except Antarctica, and many of them are causative agents of disease. Recent literature indicates a sharp increase in the number of cases in developed non-endemic countries, pointing to a current escalation of 'imported leishmaniasis'

\footnotetext{
* Correspondence: calves@ioc.fiocruz.br

'Laboratório de Biologia Molecular e Doenças Endêmicas, Av. Brasil 4365, Rio de Janeiro - CEP 21040-360, Brasil

Full list of author information is available at the end of the article
}

cases [1]. In this epidemiologic context, Leishmania (Vianna) braziliensis, Leishmania (Leishmania) amazonensis and Leishmania (Leishmania) chagasi are the major causative agents of leishmaniasis in Brazil and, thus, are a significant public health issue [2].

During the life cycle of these parasites, they present two major morphological forms: extracellular promastigotes with visible flagellum, which multiply in the midgut of the sandfly vector, and intracellular non-motile amastigotes, that live within macrophages of the vertebrate host [3]. These parasites are transmitted to the mammalian host during the blood meal of infected sandfly vectors of the genus Lutzomyia (in the Americas). Sandflies inoculate extracellular promastigotes at the bite site, which are
C Biomed Central

() 2011 Côrtes et al; licensee BioMed Central Ltd. This is an Open Access article distributed under the terms of the Creative Commons Attribution License (http://creativecommons.org/licenses/by/2.0), which permits unrestricted use, distribution, and reproduction in any medium, provided the original work is properly cited. 
then phagocytosed by macrophages [4]. Complex interactions occur between Leishmania parasites and their sandfly vectors. Leishmania promastigotes live exclusively within the midgut of sandflies and attach to it using surface glycoconjugates, a key step in establishment of the infection. Differentiation of promastigotes to mammal-infective stages is characterized by significant biochemical and cellular remodeling [4]. Leishmania spp. differentiation, maturation and replication in vitro has been achieved in cultures of human macrophage cells [5,6]; J774 (murine) macrophages [7,8]; fibroblast cell lines $[9,10]$, epithelial cells [11], dendritic cells [12,13], neutrophil granulocytes [14]; Aedes albopictus cells [15], and Aedes aegypti cells [16,17], however, there are few studies about the life cycle of Leishmania promastigotes in phlebotomine sandflies which use insect cell lines [18,19].

Previous studies describe the establishment and characterization of a continuous cell line from Lutzomyia longipalpis, designated Lulo. These studies, demonstrated the susceptibility of this cell line to infections with arboviruses and Leishmania (Leishmania) chagasi $[18,20]$. The Lulo cell line is composed of epitheloid cells, originated from Lu. longipalpis embryonic tissue, that was obtained from adult insects collected and colonized in Colombia. The morphological, cytogenetical and biochemical characteristics of this cell line have already been studied [18]. The aim of this study is to emphasize new aspects in events of adhesion of three Leishmania species to cells from the Lulo cell line.

\section{Adhesion assays}

In the present study, promastigotes of $L$. (L.) amazonensis (MHOM/BR/77/LTB0016), L. (V.) braziliensis (MCAN/ BR/1998/619) and L. (L.) chagasi (MCAN/BR/2008/1112) were used. Parasites $\left(10^{6}\right.$ cells $\left./ \mathrm{mL}\right)$ were grown in BHI medium supplemented with $10 \%$ fetal calf serum (FCS) and maintained at $28^{\circ} \mathrm{C}$. The insect epithelioid cell line Lulo was cultured in a 1:1 mix of L15 and Grace media supplemented with $10 \%$ FCS, penicillin $(100 \mathrm{U} / \mathrm{mL})$ and streptomycin $(100 \mathrm{ug} / \mathrm{mL})$, incubated at $28^{\circ} \mathrm{C}$. Confluent monolayers were seeded on glass coverlips inside wells of a 24 well plate, to a final number of $2 \times 10^{5}$ cells per well, prior to interaction with parasites.

For kinetic studies of Lulo cells and promastigote interactions, a ratio of about 10:1 parasites/cells was used. Two hours after co-incubation non-adhered promastigotes were removed by three washing cycles with phosphatebuffered saline (PBS) pH 7.2 and cell cultures were followed for 24, 48 and 72 hours. The attached cells were fixed with methanol and stained with Giemsa.

For scanning electron microscopy assays, coverslips containing Lulo cells and parasites were incubated $\left(1 \mathrm{~h}, 25^{\circ} \mathrm{C}\right)$ with $0.1 \mathrm{M}$ sodium cacodylate buffer $\mathrm{pH} 7.2$ containing
2.5\% glutaraldehyde and 3.5\% sucrose, followed by a second incubation $\left(1 \mathrm{~h}, 25^{\circ} \mathrm{C}\right)$ with $1 \%$ osmium tetroxide and dehydrated in acetone. Afterwards, coverslips were dried with $\mathrm{CO}_{2}$ in a critical point dryer and coated with gold. Samples were examined in a scanning electron microscope (Jeol JSM-6390LV).

\section{Quantification and visualization of adhesion}

The optical microscopy analysis indicates a greater potential of species from the subgenus Leishmania to adhere to Lulo cells when compared to parasites from the subgenus Viannia (Figure 1). L. (L.) chagasi has the highest adhesion rate to Lulo cells (between $2 \mathrm{~h}$ to $72 \mathrm{~h}$ of interaction), followed respectively by $L$. (L.) amazonensis and $L$. (V.) braziliensis. Additionally, results point to differences with statistical significance for the adhesion rates (between $2 \mathrm{~h}$ to $72 \mathrm{~h}$ of interaction) of $L$. (V.) braziliensis $\times L$. (L.) amazonensis $(\mathrm{P}=0.010)$, L. (V.) braziliensis $\times$ L. (L.) chagasi $(\mathrm{p}$ $=0.020)$, L. $($ L. $)$ chagasi $\times$ L. $($ V.) braziliensis $(\mathrm{p}=0.020)$ and $L$. (L.) chagasi $\times$ L. (L.) amazonensis $(\mathrm{p}=0.003)$. Peaks of adhesion were observed after $24 \mathrm{~h}$ of incubation with Lulo cells for $L$. (L.) chagasi $(27.3 \pm 1.8 \%$ of cells with adhered promastigotes) and $48 \mathrm{~h}$ for $L$. (L.) amazonensis $(16.0 \pm 0.7 \%)$ and L. (V.) braziliensis (3 $\pm 0.7 \%)$, (Figure 1$)$.

The fact that $L$. $(V)$ braziliensis showed a lower adhesion rate to Lulo cells when compared to $L$. (L) amazonensis and $L$. $(L)$ chagasi is an interesting and unexpected finding: as $L u$. longipalpis is reported as an efficient vector for species of the subgenera Leishmania, like L. (L) chagasi [21], and as Lulo cells are derived from this sand fly species, it was reasonable to suppose that these cells would be more susceptible to adherence to parasites from the subgenera Leishmania. Thus, further studies are required to identify and understand the molecules related to promastigote adhesion on the surface of Lulo cells. Moreover, these results suggest that the Lulo cell line can be applied to studies of insect-parasite interactions for both tegumentary and visceral Leishmania species.

The present results suggest that this model of interaction could, at some level, be due to the strong adhesion observed between parasites and Lulo cells, which mimic the events that take place in the digestive tract of infected insects. Differences between adhesion rates of the three studied Leishmania species may indicate the presence of specific and distinct molecules involved in this process for each species [22].

Scanning electron microscopy analysis showed that Lulo cells, when cultured in vitro, have either a rounded morphology or become sprawled with cytoplasmic processes (Figure 2a). Adhesion of promastigotes from the three studied Leishmania species to Lulo cells can occur by flagellum only or simultaneously by body and flagellum (Figure 2b-d). On the other hand, the interaction of Lulo cells with $L$. (L.) chagasi showed the participation of 

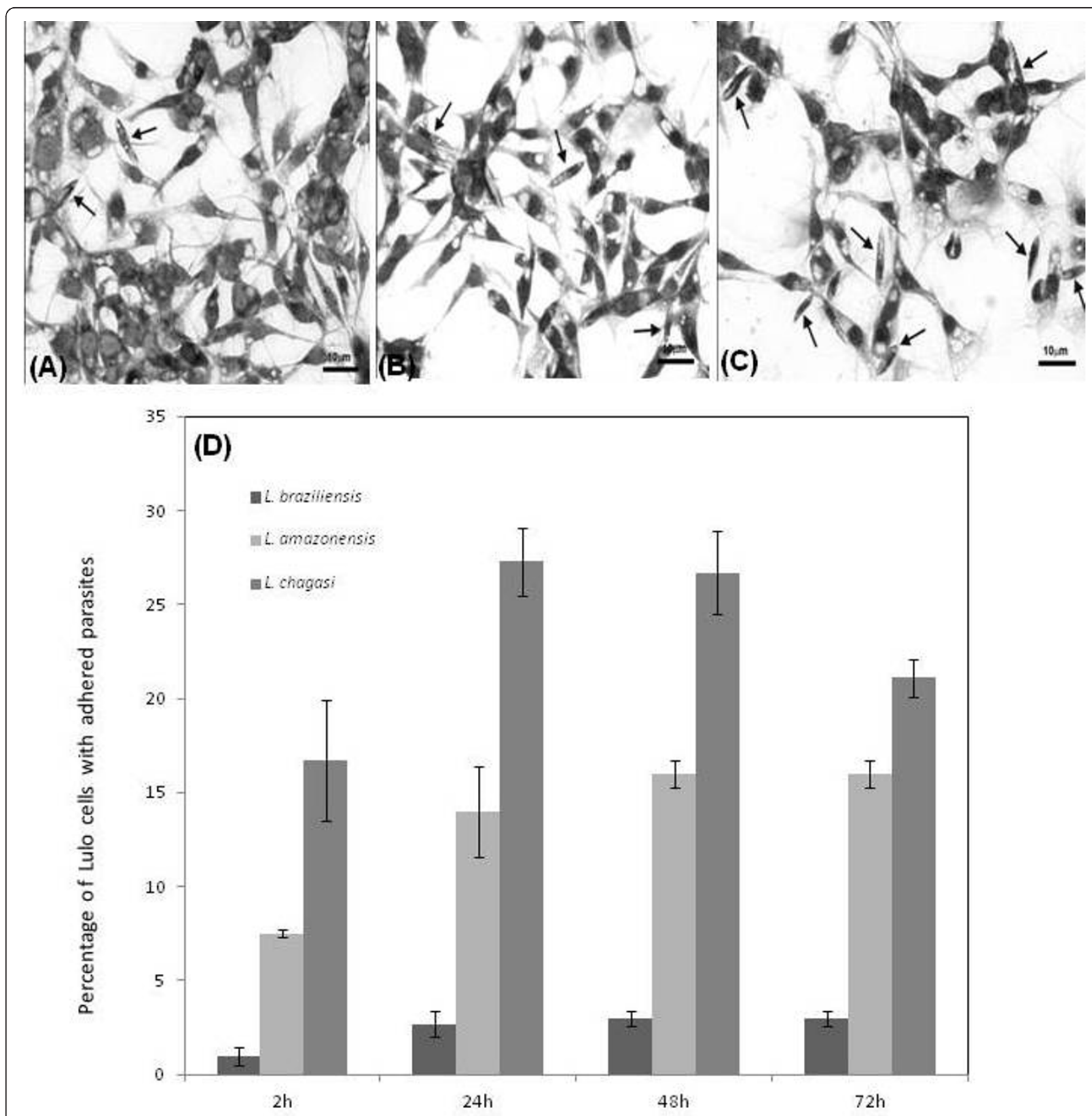

Figure 1 Analysis of promastigote adhesion to Lulo cells. After interaction between Lulo cells and promastigotes, the samples were stained with Giemsa for analysis. In the figure, the arrows are indicating the promastigotes adhered to Lulo cells at $48 \mathrm{~h}$ for Leishmania (V.) braziliensis (A), Leishmania (L.) amazonensis (B) and $24 \mathrm{~h}$ for Leishmania (L.) chagasi (C). Quantitative data (D) of the interaction were assessed at different times (2 h; $24 \mathrm{~h} ; 48 \mathrm{~h} ; 72 \mathrm{~h}$ ) of incubation. Data are expressed in percentile values (\%) and represent average and standard deviation of five independent experiments.

cytoplasmic projections, which closely associated the parasites to the cells (Figure 2-d).

In the invertebrate host, adhesion of promastigotes to gut epithelium is an essential step for the maintenance of the life cycle. Adhesion of parasites is directly related to the expression of membrane molecules, such as phosphoglycans and glycoproteins [23-30], distributed along their surface. Although there are currently a variety of cell lines and cell free media available to study the transformations occurring during the life cycle of different Leishmania 

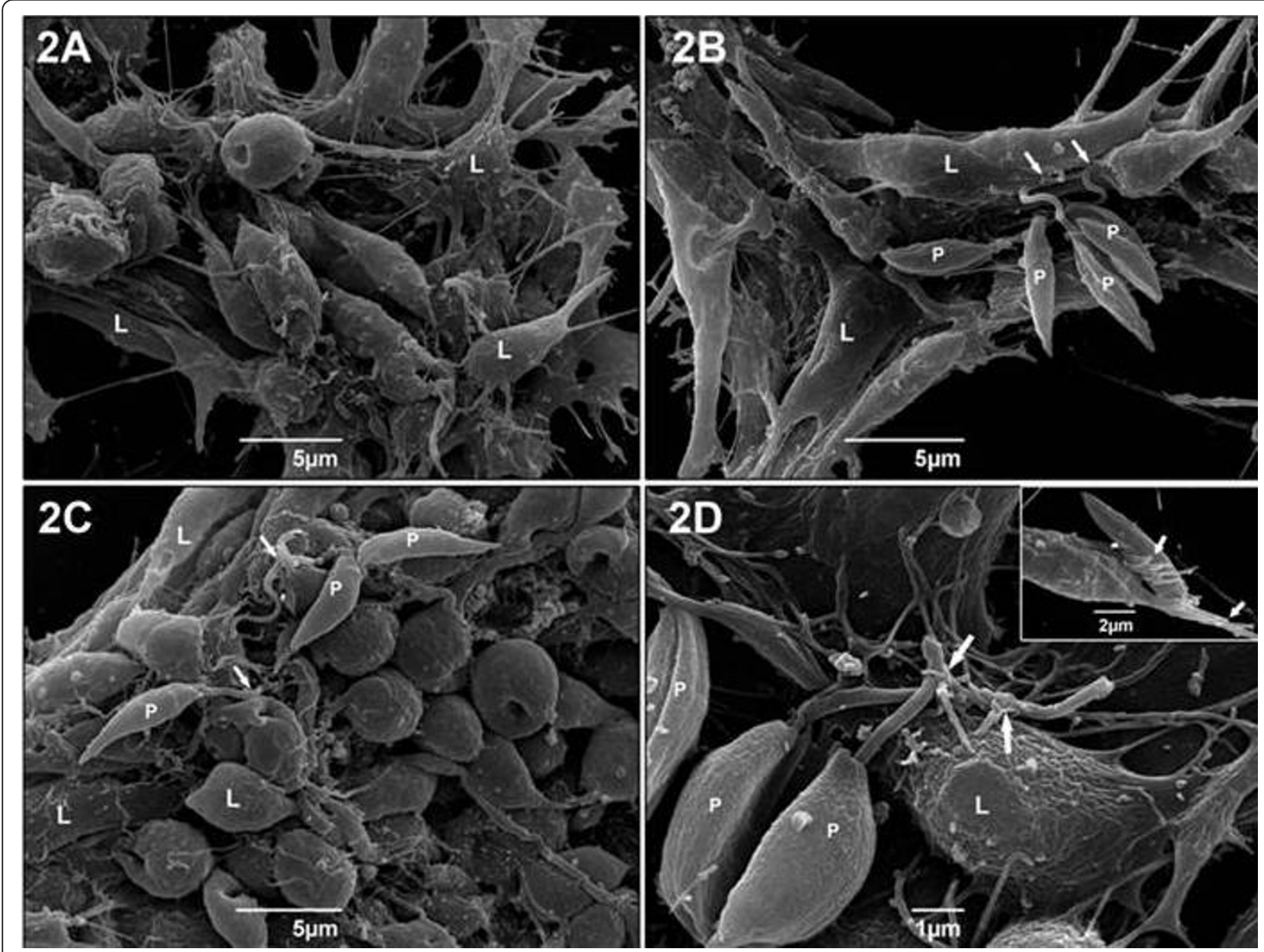

Figure 2 Scanning electron microscopy showing the interaction of promastigotes and Lulo cells. Electron micrographs show adhesion of parasites from three Leishmania species (P) with Lulo cells (L). A - Lulo cells; in vitro, present rounded morphology or sprawled with cytoplasmic projections. B - Leishmania (V.) braziliensis; adhesion occurs by flagellum (arrows) with tenuous contact between both cells and parasite. C-D Interaction of species from the subgenus Leishmania with Lulo cells; occurs by both flagellum and body. C- Leishmania (L.) amazonensis; promastigotes are adhered by both body and flagellum (arrows) to cytoplasmic membrane of Lulo cells. D - Interaction of Lulo cells with Leishmania (L.) chagasi; occurs with participation of cytoplasmic projections involving the flagellum (arrows). In detail, we show flagellum (arrows) and body (arrows) of parasites that are being enveloped by several cytoplasmic projections of Lulo cells - inset - D. Images were assessed after $24 \mathrm{~h}(\mathrm{D})$ and $48 \mathrm{~h}$ (B and $\mathrm{C})$ of interaction.

species in mammals, there is little information regarding this process in cell cultures obtained from phlebotomine sandfly vectors.

\section{Conclusion}

We have presented evidence that the Lulo cell line can be useful as a model for studies of insect-parasite interactions for Leishmania species. Further experiments that can bring significant contributions on understanding the biological cycle of these parasites during infection of insect cells are still necessary. Our present perspectives are targeted at confirming the potential of this model as an appropriate biological tool for studies of cell interactions with Leishmania spp.

\section{Acknowledgements}

We are grateful to the Electron Microscopy Platform of Oswaldo Cruz Institute/Fiocruz and Vanessa Alvaro Diniz for technical support. Luzia M. C. Côrtes, MSc, is a doctoral student of Fiocruz institution, Dr. Bernardo A. S. Pereira is a postdoctoral researcher fellow of CAPES/FAPERJ and Dr. Carlos R. Alves is fellow researcher of CNPq institution.

\section{Author details}

'Laboratório de Biologia Molecular e Doenças Endêmicas, Av. Brasil 4365, Rio de Janeiro - CEP 21040-360, Brasil. " Laboratório de Biologia Estrutural, Av. Brasil 4365, Rio de Janeiro - CEP 21040-360, Brasil. ${ }^{3}$ Departamento de

Ciencias Básicas, Universidad De La Salle, Carrera 2 No. 10-70, D.C., Colombia. ${ }^{4}$ Universidad Del Rosário, Escuela de Medicina, Carrera 24 no 63C-69, Bogotá, D.C. Colombia. ${ }^{5}$ Laboratório Imunoparasitologia - IOC - FIOCRUZ, Av. Brasil 4365, Rio de Janeiro - CEP 21040-360, Brasil. "'Laboratório de Vigilância em Leishmanioses - IPEC - FIOCRUZ, Av. Brasil 4365, Rio de Janeiro - CEP 21040360, Brasil. 'Laboratório de Bioquímica e Fisiologia de Insetos, Av. Brasil 4365, Rio de Janeiro - CEP 21040-360, Brasil. 


\section{Authors' contributions}

LMCC, RPB and CRA formulated the idea and wrote the manuscript; LMCC, ACZ, RMMS, CG, LCF and MFM performed the experimental processes. BASP, SCR and FJB provided critical comments to the protocol and the discussion. All authors approved the final version of this manuscript.

\section{Competing interests}

The authors declare that they have no competing interests.

Received: 19 August 2011 Accepted: 14 November 2011 Published: 14 November 2011

\section{References}

1. Pavli A, Maltezou HC: Leishmaniasis, an emerging infection in travellers. Int J Infect Dis 2010, 14:e1032-9.

2. Lainson R: The Neotropical Leishmania species: a brief historical review of their discovery, ecology and taxonomy. Rev Pan-Amaz Saude 2010, 1:13-32.

3. Bates PA, Rogers ME: New insights into the developmental biology and transmission mechanisms of Leishmania. Curr Mol Med 2004, , 4: 601-609.

4. Bates PA: Leishmania sand fly interaction: progress and challenges. Curr Opin Microbiol 2008, 11:340-344.

5. Gantt KR, Goldman TL, McCormick ML, Miller MA, Jeronimo SMB, Nascimento ET, Britigan BE, Wilson ME: Oxidative responses of human and murine macrophages during phagocytosis of Leishmania chagasi. J Immunol 2001, 167:893-901.

6. Silva SdeO, Wu AA, Evans DA, Vieira LQ, Melo MN: Leishmania sp isolated from human cases of cutaneous leishmaniasis in Brazil characterized as Leishmania major-like. Acta Trop 2009, 112:239-248.

7. Chang KP, Reed SG, McGwire BS, Soong L: Leishmania model for microbial virulence: the relevance of parasite multiplication and pathoantigenicity. Acta Trop 2003, 85:375-390.

8. Wanderley JL, Pinto da Silva $L H$, Deolindo P, Soong L, Borges VW, Prates DB, de Souza AP, Barral A, Balanco JM, do Nascimento MT, Saraiva EM, Barcinski MA: Cooperation between apoptotic and viable metacyclics enhances the pathogenesis of leishmaniasis. PLOS One 2009, 4:e5733.

9. Corte-Real S, Santos CB, Meiralles MNL: Differential expression of the plasma membrane $\mathrm{Mg}^{2+}$ ATPase and $\mathrm{Ca}^{2+}$ ATPase activity during adhesion and interiorization of Leishmania amazonensis in fibroblasts in vitro. J Submicros Cytol Parasitol Pathol 1995, 27:359-366.

10. Hespanhol RC, de Nazaré C Soeiro M, Meuser MB, de Nazareth SL Meirelles $M$, Corte-Real $S$ : The expression of mannose receptors in skin fibroblast and their involvement in Leishmania (L.) amazonensis invasion. J Histochem Cytochem 2005, 53:35-44.

11. Pessotti JH, Zaverucha Do Valle T, Corte-Real S, Conçalves da Costa SC: Interaction of Leishmania (L.) chagasi with the vero cell line. Parasite 2004, 11:99-102.

12. Jebbari H, Stagg AJ, Davidson RN, Knight SC: Leishmania major promastigotes inhibit dendritic cell motility in vitro. Infect Immun 2002, 70:1023-1026.

13. Colmenares M, Corbi AL, Turco SJ, Rivas J: The dendritic cells receptor DCSIGN discriminates among species and life cycle forms of Leishmania. $J$ Immunol 2004, 172:1186-1190.

14. Laskay T, Zandbergen G, Slobach W: Neutrophil granulocytes - Trojan horses for Leishmania major and other intracellular microbes? Trends Microbiol 2003, 11:210-214

15. Dedet JP, Gaudin OG: Leishmania donovani multiplication in a cell line Aedes albopictus. Trans R Soc Trop Med Hyg 1976, 70:535-536.

16. Miranda AA, Sarmiento L, Caldas ML, Zapata C, Bello FJ: Morphology and cytochemistry of Aedes aegypti's cell cultures (Diptera: Culicidae) and susceptibility to Leishmania panamensis (Kinetoplastida: Trypanosomatidae). Rev Biol Trop 2008, 56:447-458.

17. Münoz-Camargo C, Barreto A, Bello F: Análisis de la susceptibilidad de una línea celular de Aedes aegypti (Diptera: Culicidae) a la infección com Leishmania (L) chagasi y Leishmania (V) braziliensis. Rev Cienc Salud Bogotá (Colombia) 2005, 3:119-128.

18. Rey G, Ferro C, Bello F: Establishment and characterization of a new continuous cell line from Lutzomyia longipalpis (Diptera: Psychodidae) and its susceptibility to infections with arboviruses and Leishmania chagasi. Mem Inst Oswaldo Cruz 2000, 95:103-110.
19. Zapata Lesmes AC, Cárdenas Castro E, Bello F: Characterization of cell cultures derived from Lutzomyia spinicrassa (Diptera: Psychodidae) and their susceptibility to infection with Leishmania (Vianna) braziliensis. Med Sci Monit 2005, 11:457-464.

20. Bello FJ, Mejía AJ, Corena MP, Ayala M, Sarmiento L, Zúñiga C, Palau MT: Experimental infection of Leishmania (L.) chagasi in a cell line derived from Lutzomyia longipalpis (Diptera: Psychodidae). Mem Inst Oswaldo Cruz 2005, 100:619-625.

21. Killick-Kendrick R: Phlebotomine vectors of the leishmaniases: a review. Med Vet Entomol 1990, 4:1-24.

22. Alves CR, Côrtes LMC, Brazil RP: The vectorial potential of Lutzomyia (Nyssomyia) intermedia and Lutzomyia (N.) whitmani in the transmission of Leishmania (V.) braziliensis can also be related to proteins attaching. J Biomed Biotechnol 2010, 2010:827851.

23. Saraiva EM, Pimenta PF, Brodin TN, Rowton E, Modi GB, Sacks DL: Changes in lipophosphoglycan and gene expression associated with the development of Leishmania major in Phlebotumus papatasi. Parasitology 1995, 111:275-287.

24. Sacks DL, Hieny S, Sher A: Identification of cell surface carbohydrate and antigenic chances between noninfective and infective developmental stages of Leishmania major promastigotes. J Immunol 1985, 135:564-569.

25. Sacks DL, Saraiva EM, Rowton E, Turco SJ, Pimenta PF: The role of the lipophosphoglycan of leishmania in vector competente. Parasitology 1994, 108(suppl)::55-62.

26. Pimenta PF, Saraiva EM, Sacks DL: The comparative fine structure and surface glycoconjugate expression of three life stages of Leishmania major. Exp Parasitol 1991, 72:191-204.

27. Sacks DL, Kamhawi S: Molecular aspects of parasite-vector and vectorhost interactions in leishmaniosis. Am Rev Microbiol 2001, 55:453-483.

28. Fampa P, Correa-da-Silva MS, Oliveira SM, Motta MC, Saraiva EM: Interaction of insect trypanosomatids with mosquitoes, sans fly and the respective insect cell lines. Int J Parasitol 2003, 33:1019-1026.

29. Novozhilova NM, Bovin NV: Structure, functions, and biosynthesis of glycoconjugates of Leishmania spp. cell surface. Biochemistry 2010, 75:686-694.

30. Myskova J, Svobodava M, Beverley SM, Volf P: A lipophosphoglycanindependent development of leishmania in permissive sand flies. Microbes and infection 2007, 9:317-324.

doi:10.1186/1756-3305-4-216

Cite this article as: Côrtes et al: Lulo cell line derived from Lutzomyia longipalpis (Diptera: Psychodidae): a novel model to assay Leishmania spp. and vector interaction. Parasites \& Vectors 2011 4:216

\section{Submit your next manuscript to BioMed Central and take full advantage of:}

- Convenient online submission

- Thorough peer review

- No space constraints or color figure charges

- Immediate publication on acceptance

- Inclusion in PubMed, CAS, Scopus and Google Scholar

- Research which is freely available for redistribution 